\title{
Believe it or not: Views of a sample of Egyptian women about sexual myths
}

\author{
Original \\ Article \\ Ihab Younis ${ }^{1}$, Menha A. Ibrahim ${ }^{1}$ and Fatima-Alzahraa A Abdel-Munem ${ }^{2}$ \\ ${ }^{I}$ Department of Dermatology and Andrology, Faculty of Medicine, Benha University, Benha, \\ and ${ }^{2}$ El-Qinnayat Central Hospital-Sharqia Governorate, Egypt
}

\begin{abstract}
Background: Many people have sexual dysfunctions for the simple reason that they believe in certain fallacies and mythical ideas.

Aim: To assess the opinion of female doctors compared with nonmedical women regarding sexual myths.

Patients and Methods: Participants included 822 married women divided into two groups: a medical group including 432 (52.6\%) female doctors (not working in the field of sexual medicine) and a nonmedical group including 390 (47.4\%) women. The tool was a self-report questionnaire to assess opinions about eight sexual myths in addition to demographic data.

Results: Most nonmedical women believed in seven of the eight myths, whereas most female doctors believed in only two myths. Age of women, their residence, and their educational level were determining factors in believing sexual myths.

Conclusion: Nonmedical women are more liable to believe in sexual myths. The need to spread proper sexual knowledge via sexual education is a dire need.
\end{abstract}

Key Words: Beliefs, myths, opinions, women.

Received: 21 November 2020, Accepted: 23 November 2020.

Corresponding Author: Ihab Younis, Department of Dermatology and Andrology, Faculty of Medicine, Benha University, Benha, Egypt, Tel.: 01017186419, E-mail: ihabyounis@hotmail.com

ISSN: 2090-6048, 2021

\section{INTRODUCTION}

The word "myth" comes from Greek "mythos" which means anything delivered by word of mouth ${ }^{[1]}$. Sexual myths are beliefs which are exaggerated, incorrect, not based on scientific foundation, or considered as true but in fact not in terms of sexuality ${ }^{[2]}$.

Sexual myths were always present throughout history. Ancient practitioners of Taoism believed that sex without ejaculating makes life longer ${ }^{[3]}$, Hippocratic physicians had dietary prescriptions for choosing the sex of one's children ${ }^{[4]}$ and there are many stories of toothed vaginas (vagina dentata) throughout the world. If these teeth are not removed, the male fears that his penis or testicles, or both, will be sheared away. Some argue that these stories are the backbone to the practice of female genital mutilation ${ }^{[5]}$.

Many reasons make myths be prevalent in a population. Examples of these reasons are: poor education, cultural beliefs and social misconceptions. Myths are usually passed on from one generation to the next ${ }^{[6]}$.

Long lasting myths tend to become believed in as true. Sexuality-related myths can lead to sexual dysfunction, the development of adversely affected gender identity and decrease in the quality of sexual intercourse ${ }^{[7]}$.
The current study was carried out in order to compare the credibility of some sexual myths among a sample of female doctors (not trained in sexual medicine) and non-medical Egyptian women.

\section{PATIENTS AND METHODS}

This cross-sectional study was started after obtaining approval from the Department of Dermatology and Andrology and the Research Ethics Committee in Faculty of Medicine, Benha University.

The participants were 822 married women recruited from the Dermatology and Andrology outpatient clinic in Benha University and El-Qinnayat Central HospitalSharqia governorate. Participants were divided into 2 groups: The medical group including 432 female doctors (non-andrologists) $(52.6 \%)$ and the non-medical group including 390 women (47.4\%).

The tool used was a self-report questionnaire which included questions about demographic data plus 8 statements which participants were asked to give their opinion about the credibility of these statements. These statements were given to participants as shown below or as questions for them to choose from some choices.

1. Normal coital frequency is once daily ${ }^{[8]}$ 
2. Normal coital duration can take more than half an hour $^{[9]}$

3. Sexual activity stops after a certain age ${ }^{[10]}$

4. Hairy men have more sexual powers than smooth $\operatorname{man}^{[11]}$

5. There is a relation between size of a man's penis and size of his shoes ${ }^{[12]}$

6. Sex should happen only if a man initiates $i^{[13]}$

7. Certain foods affect sexual desire ${ }^{[14]}$

8. Masturbation is harmful ${ }^{[15]}$

The aim of the study was explained to the women before taking their informed consent and asking them to fill the questionnaire. To ensure that all gathered information was kept confidential and the subject was anonymous, each questionnaire was handed in an open envelope and after filling it; the subject sealed the envelope and put it in a basket containing other sealed envelopes.

Participants were married Egyptian women not suffering from diseases that impair sexuality. Illiterate women were excluded from the study as women should be able to read and write in order to fill the questionnaire by themselves.

\section{Statistical analysis}

Results were collected, tabulated, statistically analyzed by a personal computer and statistical package SPSS version 20 (IBM Corp., Armonk, N.Y., USA). Two types of statistics were done.

(1) Descriptive, for example, number and percent.

(2) Analytical:

(a) $\chi^{2}$ : it is used to compare between two groups or more regarding one qualitative variable in $2 \times 2$ contingency table or $\mathrm{r}$ c complex table.

(b) $\mathrm{Z}$ test: between proportions.

(c) Pvalue

(i) Nonsignificant difference if $P$ value more than 0.05 .

(ii) Significant difference if $P$ value less than 0.05 .

(iii) Highly significant difference if $P$ value less than 0.001 .

\section{RESULTS}

\section{Demographic data}

The most common age group in participants was 30-39 years $(53.5 \%)$. Employed participants in the medical group were $372(86.1 \%)$ women, whereas employed women in the nonmedical group were $34.4 \%$. In the medical group, most women $(86.3 \%)$ were living in urban areas, whereas most women in the nonmedical group $(82.1 \%)$ were living in rural areas (Table 1).

Table 1: Demographic data

\begin{tabular}{|c|c|c|c|c|c|}
\hline Variables & Medical group $(N=432)[\mathrm{n}(\%)]$ & Nonmedical group $(N=390)[\mathrm{n}(\%)]$ & Total $(N=822)[\mathrm{n}(\%)]$ & $\chi^{2}$ test & $P$ value \\
\hline \multicolumn{6}{|l|}{ Age (years) } \\
\hline$<20$ & 0 & $17(4.4)$ & $17(2.1)$ & 139.7 & $<0.001^{* *}$ \\
\hline $20-29$ & $139(32.2)$ & $88(22.6)$ & $227(27.6)$ & & \\
\hline $30-39$ & $277(64.1)$ & $163(41.8)$ & $440(53.5)$ & & \\
\hline $40-49$ & $12(2.8)$ & $55(14.1)$ & $67(8.2)$ & & \\
\hline$\geq 50$ & $4(0.9)$ & $67(17.2)$ & $71(8.6)$ & & \\
\hline \multicolumn{6}{|l|}{ Educational level } \\
\hline Read and write & 0 & $77(19.7)$ & $77(9.4)$ & 255.96 & $<0.001^{* *}$ \\
\hline Secondary school & 0 & $111(28.5)$ & $111(13.5)$ & & \\
\hline University graduate & $432(100)$ & $202(51.8)$ & $634(77.1)$ & & \\
\hline \multicolumn{6}{|l|}{ Place of residence } \\
\hline Village & $59(13.7)$ & $320(82.1)$ & $379(46.1)$ & 385.8 & $<0.001^{* *}$ \\
\hline City & $373(86.3)$ & $70(17.9)$ & $443(53.9)$ & & \\
\hline \multicolumn{6}{|l|}{ Occupation } \\
\hline Student & 0 & $45(11.5)$ & $45(5.5)$ & 232.45 & $<0.001^{* *}$ \\
\hline Employed & $372(86.1)$ & $134(34.4)$ & $506(61.5)$ & & \\
\hline No job & $60(13.9)$ & $211(54.1)$ & $271(33.0)$ & & \\
\hline
\end{tabular}

${ }^{* *}$ Highly significant difference $(P<0.001)$. 


\section{Reaction of studied women to sexual myths}

Table 2 shows that most nonmedical women believed the following statements: normal frequency of intercourse is at least once daily $(56.7 \%)$, normal coital duration is more than half an hour $(58.5 \%)$, sexual activity stops after a certain age $(81.3 \%)$, hairy men have more sexual powers than smooth man (48.5\%), a man is supposed to allude for sexual intercourse (77.2\%), certain foods (mainly sea food $68.9 \%$ ) increase sexual desire (64.4\%), and masturbation is harmful $(79.5 \%)$. A majority of women of the medical group disagreed with the nonmedical women in all aspects except for two aspects: certain foods (mainly sea food $86.3 \%$ ) increase sexual desire $(54.4 \%)$ and masturbation is harmful $(79.5 \%)$.

Table 2: Sexual myths in the studied groups

\begin{tabular}{|c|c|c|c|c|c|}
\hline Variables & Medical group $(N=432)[\mathrm{n}(\%)]$ & Nonmedical group $(N=390)[\mathrm{n}(\%)]$ & Total $(N=822)[\mathrm{n}(\%)]$ & $\chi^{2}$ test & $P$ value \\
\hline \multicolumn{6}{|c|}{ Normal frequency of intercourse is at least once daily } \\
\hline Yes & $128(29.6)$ & $221(56.7)$ & $349(42.5)$ & 61.33 & $<0.001^{* *}$ \\
\hline No & $304(70.4)$ & $169(43.3)$ & $473(57.5)$ & & \\
\hline \multicolumn{6}{|c|}{ Normal coital duration is $>30 \mathrm{~min}$} \\
\hline Yes & $84(19.4)$ & $228(58.5)$ & $312(38.0)$ & 132.5 & $<0.001^{* *}$ \\
\hline No & $348(80.6)$ & $162(41.5)$ & $510(62.0)$ & & \\
\hline \multicolumn{6}{|c|}{ Sexual activity stops after the age of } \\
\hline 40 & $4(0.9)$ & $35(9.0)$ & $39(4.7)$ & 300.0 & $<0.001^{* *}$ \\
\hline 50 & $36(8.3)$ & $127(32.6)$ & $163(19.8)$ & & \\
\hline 60 & $51(11.8)$ & $155(39.7)$ & $206(25.1)$ & & \\
\hline $\begin{array}{l}\text { No age for stopping } \\
\text { sex }\end{array}$ & 341 (78.9) & $73(18.7)$ & $414(50.4)$ & & \\
\hline \multicolumn{6}{|c|}{ Hairy men have more sexual powers than smooth man } \\
\hline Yes & $79(18.3)$ & $189(48.5)$ & $268(32.6)$ & 84.93 & $<0.001^{* *}$ \\
\hline No & $353(81.7)$ & $201(51.5)$ & $554(67.4)$ & & \\
\hline \multicolumn{6}{|c|}{ There is a relation between size of a man's penis and size of his shoes } \\
\hline Yes, there is a relation & $36(8.3)$ & $83(21.3)$ & $119(14.5)$ & 136.6 & $<0.001^{* *}$ \\
\hline $\begin{array}{l}\text { Yes, their sizes are } \\
\text { equal }\end{array}$ & $7(1.6)$ & $90(23.1)$ & $97(11.8)$ & & \\
\hline No, there is no relation & $389(90.0)$ & $217(55.6)$ & $606(73.7)$ & & \\
\hline \multicolumn{6}{|c|}{ Who is supposed to allude for sexual intercourse } \\
\hline Woman & $3(0.7)$ & 0 & $3(0.4)$ & 195.3 & $<0.001^{* *}$ \\
\hline Man & $123(28.5)$ & $301(77.2)$ & $424(51.6)$ & & \\
\hline No matter who & $306(70.8)$ & $89(22.8)$ & $395(48.1)$ & & \\
\hline \multicolumn{6}{|c|}{ Certain foods affect sexual desire } \\
\hline Yes, it increases it & $235(54.4)$ & $251(64.4)$ & $486(59.1)$ & 69.24 & $<0.001^{* *}$ \\
\hline Yes, it decreases it & 0 & $39(10.0)$ & $39(4.7)$ & & \\
\hline No & $197(45.6)$ & $100(25.6)$ & $297(36.1)$ & & \\
\hline \multicolumn{6}{|l|}{ Masturbation is harmful } \\
\hline Yes & $354(81.9)$ & $310(79.5)$ & $664(80.8)$ & 0.80 & $0.37(\mathrm{NS})$ \\
\hline No & $78(18.1)$ & $80(20.5)$ & $158(19.2)$ & & \\
\hline
\end{tabular}

${ }^{* *}$ Highly significant difference $(P<0.001)$.

${ }^{* *}$ Nonsignificant (NS) difference $(P>0.05)$. 


\section{Effect of age group on beliefs of sexual myths}

A comparison between age groups 20-29 and age group 50+ shows a significant increase of the percentage of women who believe in the following statements: normal coital duration is more than half an hour
(30.8 vs. $50.7 \%$ ), sexual activity stops after the age of 60 years ( 26.9 vs. $42.3 \%)$, men can have sex any time ( 50.7 vs. $76.1 \%$ ), husband is supposed to allude for sexual intercourse ( 46.7 vs. $83.1 \%$ ), certain foods increase sexual desire (54.2 vs. $94.4 \%$ ), and masturbation is harmful (81.5 vs. $94.4 \%)$ (Table 3$)$.

Table 3: Correlation between different age groups and sexual myths believed by the studied groups

\begin{tabular}{|c|c|c|c|c|c|c|c|}
\hline \multirow[b]{2}{*}{ Variables } & \multicolumn{7}{|c|}{$\operatorname{Age}(N=822)[\mathrm{n}(\%)]$} \\
\hline & $<20(N=17)$ & $20-29(N=227)$ & $30-39(N=440)$ & $40-49(N=67)$ & $50+(N=71)$ & $\chi^{2}$ test & $P$ value \\
\hline \multicolumn{8}{|c|}{ Normal frequency of intercourse is at least once daily } \\
\hline Yes & $17(100)$ & $112(49.3)$ & $158(35.9)$ & $45(67.2)$ & $17(23.9)$ & \multirow[t]{2}{*}{61.87} & \multirow[t]{2}{*}{$<0.001^{* *}$} \\
\hline No & 0 & $115(50.7)$ & $282(64.1)$ & $22(32.8)$ & $54(76.1)$ & & \\
\hline \multicolumn{8}{|c|}{ Normal coital duration is $>30 \mathrm{~min}$} \\
\hline Yes & $13(76.5)$ & $70(30.8)$ & $145(33.0)$ & $48(71.6)$ & $36(50.7)$ & \multirow[t]{2}{*}{57.45} & \multirow[t]{2}{*}{$<0.001^{* *}$} \\
\hline No & $4(23.5)$ & $157(69.2)$ & $295(67.0)$ & $19(28.4)$ & $35(49.3)$ & & \\
\hline \multicolumn{8}{|c|}{ Sexual activity stops after the age of } \\
\hline 40 & $7(41.2)$ & 0 & $18(4.1)$ & 0 & $14(19.7)$ & \multirow[t]{4}{*}{217.76} & \multirow[t]{4}{*}{$<0.001^{* *}$} \\
\hline 50 & $4(23.5)$ & $40(17.6)$ & $79(18.0)$ & $16(23.9)$ & $24(33.8)$ & & \\
\hline 60 & 0 & $61(26.9)$ & $75(17.0)$ & $40(59.7)$ & $30(42.3)$ & & \\
\hline No age for stopping sex & $6(35.3)$ & $126(55.5)$ & $268(60.9)$ & $11(16.4)$ & $3(4.2)$ & & \\
\hline \multicolumn{8}{|c|}{ Hairy men have more sexual powers than smooth man } \\
\hline Yes & $15(88.2)$ & $115(50.7)$ & $238(54.1)$ & $44(65.7)$ & $54(76.1)$ & \multirow[t]{2}{*}{24.51} & \multirow[t]{2}{*}{$<0.001^{* *}$} \\
\hline No & $2(11.8)$ & $112(49.3)$ & $202(45.9)$ & $23(34.3)$ & $17(23.9)$ & & \\
\hline \multicolumn{8}{|c|}{ There is a relation between size of a man's penis and size of his shoes } \\
\hline Yes, there is a relation & $4(23.5)$ & $39(17.2)$ & $59(13.4)$ & $8(11.9)$ & $9(12.7)$ & \multirow[t]{3}{*}{82.52} & \multirow[t]{3}{*}{$<0.001^{* *}$} \\
\hline Yes, their sizes are equal & $7(41.2)$ & $32(14.1)$ & $20(4.5)$ & $23(34.3)$ & $15(21.1)$ & & \\
\hline No, there are no relation & $6(35.3)$ & $156(68.7)$ & $361(82.0)$ & $36(53.7)$ & $47(66.2)$ & & \\
\hline \multicolumn{8}{|c|}{ Who is supposed to allude for sexual intercourse } \\
\hline Wife & 0 & $1(0.4)$ & $2(0.5)$ & 0 & 0 & \multirow[t]{3}{*}{71.46} & \multirow[t]{3}{*}{$<0.001^{* *}$} \\
\hline Husband & $13(76.5)$ & $106(46.7)$ & $191(43.4)$ & $55(82.1)$ & $59(83.1)$ & & \\
\hline No matter who & $4(23.5)$ & $120(52.9)$ & $247(56.1)$ & $12(17.9)$ & $12(16.9)$ & & \\
\hline \multicolumn{8}{|c|}{ Certain foods affect sexual desire } \\
\hline Yes, it increases it & $10(58.8)$ & $123(54.2)$ & $226(51.4)$ & $60(89.6)$ & $67(94.4)$ & \multirow[t]{3}{*}{93.16} & \multirow[t]{3}{*}{$<0.001^{* *}$} \\
\hline Yes, it decreases it & $2(11.8)$ & $21(9.3)$ & $14(3.2)$ & 0 & $2(2.8)$ & & \\
\hline No & $5(29.4)$ & $83(36.6)$ & $200(45.5)$ & $7(10.4)$ & $2(2.8)$ & & \\
\hline \multicolumn{8}{|l|}{ Masturbation is harmful } \\
\hline Yes & $9(52.9)$ & $185(81.5)$ & $341(77.5)$ & $62(92.5)$ & $67(94.4)$ & \multirow[t]{2}{*}{26.02} & \multirow[t]{2}{*}{$<0.001^{* *}$} \\
\hline Nossss & $8(47.1)$ & $42(18.5)$ & $99(22.5)$ & $5(7.5)$ & $4(5.6)$ & & \\
\hline
\end{tabular}

${ }^{* *}$ Highly significant difference $(P<0.001)$. 


\section{Effect of educational level on beliefs of sexual myths}

Table 4 shows a significant decrease in beliefs of sexual myths with better education. Comparing beliefs between the three degrees of education examined in the present work (can only read and write, secondary education, and university degree) gives some examples: normal frequency of intercourse is at least once daily $(72.7,55.9$, and $36.4 \%$, respectively), and food increases sexual desire (85.7, 52.3, and 57.1\%, respectively).

Table 4: Correlation between different educational levels groups and sexual myths believed by the studied groups

\begin{tabular}{|c|c|c|c|c|c|}
\hline \multirow[b]{2}{*}{ Variables } & \multicolumn{5}{|c|}{ Educational level $(N=822)[\mathrm{n}(\%)]$} \\
\hline & Can read and write $(N=77)$ & Secondary school $(N=111)$ & University degree $(N=634)$ & $\chi^{2}$ test & $P$ value \\
\hline \multicolumn{6}{|c|}{ Normal frequency of intercourse is at least once daily } \\
\hline Yes & $56(72.7)$ & $62(55.9)$ & $231(36.4)$ & 47.21 & $<0.001^{* *}$ \\
\hline No & $21(27.3)$ & $49(44.1)$ & $403(63.6)$ & & \\
\hline \multicolumn{6}{|c|}{ Normal coital duration is $>30 \mathrm{~min}$} \\
\hline Yes & $56(72.7)$ & $76(68.5)$ & $180(28.4)$ & 105.1 & $<0.001^{* *}$ \\
\hline No & $21(27.3)$ & $35(31.5)$ & $454(71.6)$ & & \\
\hline \multicolumn{6}{|c|}{ Sexual activity stops after the age of } \\
\hline 40 & $14(18.1)$ & $7(6.3)$ & $18(2.8)$ & 175.8 & $<0.001^{* *}$ \\
\hline 50 & $28(36.4)$ & $48(43.2)$ & $87(13.7)$ & & \\
\hline 60 & $28(36.4)$ & $42(37.9)$ & $136(21.5)$ & & \\
\hline No age for stopping & $7(9.1)$ & $14(12.6)$ & $393(62.0)$ & & \\
\hline \multicolumn{6}{|c|}{ Hairy men have more sexual powers than smooth men } \\
\hline Yes & $77(100)$ & $70(63)$ & $319(50.3)$ & 72.48 & $<0.001^{* *}$ \\
\hline No & 0 & $41(37)$ & $315(49.7)$ & & \\
\hline \multicolumn{6}{|c|}{ There is a relation between size of a man's penis and size of his shoes } \\
\hline $\begin{array}{l}\text { Yes, there is } \\
\text { a relation }\end{array}$ & $21(27.3)$ & $28(25.2)$ & $70(11)$ & 221.31 & $<0.001^{* *}$ \\
\hline Their sizes are equal & $42(54.5)$ & $21(18.9)$ & $34(5.4)$ & & \\
\hline No relation & $14(18.2)$ & $62(55.9)$ & $530(83.6)$ & & \\
\hline \multicolumn{6}{|c|}{ Who is supposed to allude for sexual intercourse } \\
\hline Wife & 0 & 0 & $3(0.5)$ & 120.86 & $<0.001^{* *}$ \\
\hline Husband & $77(100)$ & $83(74.8)$ & $264(41.6)$ & & \\
\hline No matter who & 0 & $28(25.2)$ & $367(57.9)$ & & \\
\hline \multicolumn{6}{|c|}{ Certain foods affect sexual desire } \\
\hline Yes, it increases & $66(85.7)$ & $58(52.3)$ & $362(57.1)$ & 72.13 & $<0.001^{* *}$ \\
\hline Yes, it decreases & 0 & $20(18)$ & $19(3.0)$ & & \\
\hline No & $11(14.3)$ & $33(29.7)$ & $253(39.9)$ & & \\
\hline \multicolumn{6}{|c|}{ Masturbation is harmful } \\
\hline Yes & $70(90.9)$ & $84(75.7)$ & $510(80.4)$ & 6.82 & $<0.001^{* *}$ \\
\hline No & $7(9.1)$ & $27(24.3)$ & $124(19.6)$ & & \\
\hline
\end{tabular}

*Significant difference $(P<0.05)$.

${ }^{* *}$ Highly significant difference $(P<0.001)$.

Nonsignificant difference $(P>0.05)$. 


\section{Effect of residence on beliefs of sexual myths}

There is a statistically significant difference between women living in rural areas compared with women living in urban areas. Urbanization decreases believing in sexual myths. Examples from (Table 5) include the following: normal coital duration is more than half an hour (60.2 vs. $19.0 \%$ ), sexual activity stops after the age of 60 years ( 33.0 vs. $18.3 \%)$, men can have sex any time ( $67.0 \mathrm{vs} 47.9 \%$ ), and husband is supposed to allude for sexual intercourse ( 76.5 vs. $30.2 \%)$.

Table 5: Correlation between different places of residence and sexual myths believed by the studied groups

\begin{tabular}{|c|c|c|c|c|}
\hline \multirow[b]{2}{*}{ Variables } & \multicolumn{4}{|c|}{ Places of residence $(N=822)[\mathrm{n}(\%)]$} \\
\hline & Rural residence $(N=379)$ & Urban residence $(N=443)$ & $\chi^{2}$ test & $P$ value \\
\hline \multicolumn{5}{|c|}{ Normal frequency of intercourse is at least once daily } \\
\hline Yes & $205(54.1)$ & $144(32.5)$ & 38.95 & $<0.001^{* *}$ \\
\hline No & $174(45.9)$ & $299(67.5)$ & & \\
\hline \multicolumn{5}{|l|}{ Normal coital duration is $>30 \mathrm{~min}$} \\
\hline Yes & $228(60.2)$ & $84(19.0)$ & 147.2 & $<0.001^{* *}$ \\
\hline No & $151(39.8)$ & $359(81.0)$ & & \\
\hline \multicolumn{5}{|l|}{ Sexual activity stops after the age of } \\
\hline 40 & $35(9.2)$ & $4(0.9)$ & 183.25 & $<0.001^{* *}$ \\
\hline 50 & $121(31.9)$ & $42(9.5)$ & & \\
\hline 60 & $125(33.0)$ & $81(18.3)$ & & \\
\hline No age for stopping sexual activity & $98(25.9)$ & $316(71.3)$ & & \\
\hline \multicolumn{5}{|c|}{ Hairy men have more sexual powers than smooth men } \\
\hline Yes & $181(47.8)$ & $87(19.6)$ & 73.49 & $<0.001^{* *}$ \\
\hline No & $198(52.2)$ & $356(80.4)$ & & \\
\hline \multicolumn{5}{|c|}{ There is a relation between size of a man's penis and size of his shoes } \\
\hline Yes, there is a relation & $72(19.0)$ & $47(10.6)$ & 103.27 & $<0.001^{* *}$ \\
\hline Yes, their sizes are equal & $86(22.7)$ & $11(2.5)$ & & \\
\hline No, there are no relation & $221(58.3)$ & $385(86.9)$ & & \\
\hline \multicolumn{5}{|c|}{ Who is supposed to allude for sexual intercourse } \\
\hline Wife & 0 & $3(0.7)$ & 175.69 & $<0.001^{* *}$ \\
\hline Husband & $290(76.5)$ & $134(30.2)$ & & \\
\hline No matter who & $89(23.5)$ & $306(69.1)$ & & \\
\hline \multicolumn{5}{|l|}{ Certain foods affect sexual desire } \\
\hline Yes, it increases & $260(68.6)$ & $226(51.0)$ & 53.07 & $<0.001^{* *}$ \\
\hline Yes, it decreases & $29(7.7)$ & $10(2.3)$ & & \\
\hline No & $90(23.7)$ & $207(46.7)$ & & \\
\hline \multicolumn{5}{|l|}{ Masturbation is harmful } \\
\hline Yes & $310(81.8)$ & $354(79.9)$ & 0.47 & 0.49 (NS) \\
\hline No & $69(18.2)$ & $89(20.1)$ & & \\
\hline
\end{tabular}

${ }^{* *}$ Highly significant difference $(P<0.001)$. 


\section{DISCUSSION}

Sexual myths are not sweeping the world but they remind us that there were some amazing misconceptions about human sexuality out there. Many of which were passed on as gospel, and some of which were even taught in schools. Some were so misleading as to be dangerous, whereas others might cause needless worry and anxiety. Nobody gets all the right information, and sometimes early information sounded right until we learned it was actually quite inaccurate ${ }^{[16]}$.

The nonmedical group was in favor of the opinion that the normal coital frequency is daily, especially those who have a modest amount of education, youngsters, and those of rural residence. This myth is against the findings of many studies. Rao and Demaris ${ }^{[17]}$ reported that the overall mean coital frequency among 3253 American women was seven coition per month. Weekly average coital frequency was two among 527 sexually active adults in Cape Town ${ }^{[18]}$, whereas an Egyptian study ${ }^{[19]}$ found that only $8.2 \%$ of 306 surveyed married women had daily coital frequency.

In the fantasy model of male sexuality, men have large penises, rock-hard erections, and can sustain sexual activity all night long ${ }^{[20]}$. It seems that many men and women hold this fantasy. Ablow ${ }^{[21]}$ found that more than $80 \%$ of men and women, in an online survey, wanted sex to last 30 min or longer. This wishful thinking was shared by $58.5 \%$ of our nonmedical participants. Corty and Guardiani ${ }^{[22]}$ comparing actual to desired time of intercourse found that both sexes wished intercourse to last more than twice as long as self-reported length (7.86 min for men and 7.03 min for women). Intravaginal ejaculation latency time was estimated in five countries (Holland, UK, Spain, Turkey, and USA). The mean time was $5.4 \mathrm{~min}^{[23]}$.

A sweeping majority (81.3\%) of our nonmedical women agreed that sexual activity stops after certain age (mostly 60+). This notion was dominant in the views of women with low level of education and those living in rural areas. Gurvinder et al. ${ }^{[24]}$ mentioned that most cultures still believe that older women were sexually retired. In fact, all natural sexual functions change as an individual ages, but they do not disappear ${ }^{[25]}$. A substantial number of women engage in vaginal intercourse, oral sex, and masturbation even in the eighth and ninth decades of life ${ }^{[26]}$. Love and intimacy remain the same as old women were in their youth, whereas in men, whether or not erectile capacity is retained, the decision to continue intimacy is often sociocultural ${ }^{[27]}$. Levine ${ }^{[28]}$ suggests that some women find a relief in their loss of sexual feelings and capacities at midlife and hide them behind the belief that they were too old for sex owing to earlier unhappy and unsatisfying sexual experiences.

The idea that hairy men possess more sexual powers was not very popular among our participants except for the youngest age group and rural residents. The presence of body hair has traditionally been symbolic of masculinity and virility ${ }^{[29]}$. This impression may be owing to the assumption that more hair means more testosterone and more testosterone means more sex drive, more erectile function, and more sexual performance ${ }^{[30]}$. However, clinical research does not support this hypothesis. For example, hairiness has not been found to correlate with traits that are associated with high testosterone levels like masculinity of voice or masculine body shape ${ }^{[31]}$. Moreover, individual variation in hairiness of men does not mean a signal of high testosterone levels and has no correlation with levels of circulating testosterone ${ }^{[32]}$.

The relation between the length of a man's penis and the size of his shoes was only believed by $44.4 \%$ of our nonmedical women, mainly among 20-29-year age group, and women who can only read and write. The argument about correlation between penile size and certain body organs is old. In 1899, Loeb ${ }^{[33]}$ found no significant correlation between penile dimensions and body height. Siminoski and Bain $^{[34]}$ found a weak correlation between foot length and stretched penile length. They concluded that the only thing anyone will learn by a man's shoes is his taste in fashion. Shah and Christopher ${ }^{[12]}$ conducted a prospective study, on 104 men, to scientifically address the issue. Their conclusion was that 'the supposed association of penile length and shoe size has no scientific basis.'

The husband but not the wife is the one who is supposed to allude for sexual intercourse. This was the choice of $77.2 \%$ of the nonmedical women and all women who can only read and write in the current study. On the contrary, $70.8 \%$ of women doctors thought that it does not matter who starts. Wusu and Isiugo-Abanihe ${ }^{[35]}$ stated that the cultural climate of the society preconditions women's mind to always wait for men to initiate sex. A Canadian study ${ }^{[36]}$ showed that men initiated heterosexual relationships more frequently than did women (49 vs. $32 \%$ ) and most initiations were nonverbal initiation (91\%). The results of an American study ${ }^{[37]}$ showed that most men currently practice male-dominated patterns of sexual initiation; however, many men desire egalitarian patterns of initiation. Men offered clear preference to be an object of desire to their female partners.

Casanova, the $18^{\text {th }}$-century famous Venetian lover, reportedly ate dozens of oysters at a time to stir arousal before his legendary trysts. Sea food was considered an aphrodisiac by $54.4 \%$ of the medical group and $64.4 \%$ of the nonmedical group. Researchers from Harvard school of medicine ${ }^{[38]}$ concluded that couples, in which both partners consumed approximately two or more sea food servings per week, had a significantly greater sexual intercourse frequency and higher fecundity. Cai et al. ${ }^{[39]}$ suggest a potential relationship between regular daily apple consumption and better sexuality in young women population. In the study of Salonia et al. ${ }^{[40]}$ women 
reporting chocolate consumption have higher FSFI scores than women who do not eat chocolate. However, when data were adjusted for age, FSFI scores were similar, regardless of chocolate consumption. Mirza et al. ${ }^{[41]}$ analyzed bivalve mollusks - a group of shellfish that includes oysters - and found they were rich in two rare amino acids, D-aspartic acid and N-methyl-D-aspartate, that trigger increased levels of sex hormones. They stressed that the oysters have to be eaten raw to be most effective. Cooking them reduces the quantity of the two key amino acids. However, in September, 2018, the $\mathrm{FDA}^{[42]}$ stated that there is no scientific evidence that raw oysters are an aphrodisiac. The FDA even warned that raw oysters contaminated with Vibrio vulnificus can be life-threatening, even fatal when eaten by someone with liver disease, diabetes, or immunodeficiency.

Masturbation was considered to be harmful by $80.8 \%$ of our participants (including $81.9 \%$ of doctors and $92.5 \%$ of women aged $50+$ ). For many millennia, even as recently as 1901, masturbation has been associated with tuberculosis, gonorrhea, epilepsy, blindness, deafness, and 'insanity' ${ }^{\text {[43] }}$. Sigmund Freud and his orthodox collaborators stressed the connection between masturbation and 'neurasthenia' ${ }^{[44]}$. Thanks to the research works of Kinsey et al. in the $1940 \mathrm{~s}^{[45]}$ and Kinsey et al. in the $1950 \mathrm{~s}^{[46]}$ and the work of Masters and Johnson in the 1960s $\mathrm{s}^{[47]}$, current medical knowledge does not consider masturbation as a cause of mental illness, physical weakness, or any type of disease or death. It is a completely normal, natural aspect of human sexual development from the undifferentiated sensorimotor pleasure response of the infant to mutual partner exchange into old age ${ }^{[43]}$.

There were some alarming results obtained from responses of the female doctors. Examples include 81.9\% believe that masturbation is harmful, $54.4 \%$ believed that certain foods booster libido, and even those $18.3 \%$ who thought that hairy men possess more sexual powers than smooth men. These answers suggest that many of the sexual beliefs of women are built on impressions rather that solid information. Sex education in the whole society and in medical schools in particular needs a strong push forward.

\section{CONCLUSION}

Believing in sexual myths is widespread among nonmedical women, especially those of rural residence, with low education, and above 50 years of age. Sex education is a dire need even for medical services providers.

\section{CONFLICT OF INTEREST}

There are no conflicts of interest.

\section{REFERENCES}

1. Online Etymology Dictionary. Myth. Available at: https://www.etymonline.com/word/myth. [Accessed June 1, 2020].

2. Golbası Z, Evcılı F, Eroglu K, Bırcan H. Sexual myths scale (SMS): development, validity and reliability in Turkey. Sex Disabil 2016; 34:75-87.

3. Bullough VL, Bullough B, (editors). Human sexuality: an encyclopedia. $\square$ : New York: Routledge; 2014.

4. Bonnard JB. Male and female bodies according to Ancient Greek physicians. Women Gender History 2014; 15:37.

5. Raitt J. The 'vagina dentata' and the 'immaculatus uterus divinifontis'. J Am AcadRelig,1980; 48:415-431.

6. Rai M, Kishore J. Myths about diabetes and its treatment in North Indian population. Int J Diabetes Dev Ctries 2009; 29:129-132.

7. Ejder Apay S, Ozorhan EY, Ozkan H, Arslan S, Koc E, Ozbey I. The sexual beliefs of Turkish men: comparing the beliefs of men with and without erectile dysfunction. J Sex Marital Ther 2015; 41:661-671.

8. International Society of Sexual Medicine. What is the 'normal' frequency of sex? Available at: www. issm.info/sexual-health-qa/what-is-the-normalfrequency-of-sex/. [Accessed May 29, 2020].

9. Institute for Urologic Diseases. 12 myths about sex. Available at: www.imop.gr/en/sex/myths-aboutsex\#diarkeia\%20seksoualikis\%20praksis. [Accessed June 1, 2020].

10. Hammond D, Sink JM. Myths and realities of sexual aging: implications for counseling. Couns Values 1980; 24:155-165.

11. Good to know. 7 undeniable reasons why men with hairy chests make the best partners. Available at:https://www.goodtoknow.co.uk/wellbeing/ relationships/reasons-why-men-with-hairy-chestsmake-the-best-partners-4815. [Accessed June 6, 2020].

12. Shah J, Christopher N. Can shoe size predict penile length?. BJU Int 2002; 90:586-587.

13. Nobre P, Gouveia JP, Gomes FA. Sexual dysfunctional beliefs questionnaire: an instrument to assess sexual dysfunctional beliefs as vulnerability factors to sexual problems. Sex Relatsh Ther 2003; 18:171-204. 
14. Caroll AE. 8 myths about sex you need to stop believing. Available at: https://www.businessinsider. com/myth s-about-sex-you-need-to-stopbelieving-2018-6. [Accessed May 30, 2020].

15. Quilliam S. Sexual myths. BMJ Sex Reprod Health 2005; 31:158-159.

16. Schwartz P, Kempner M. 50 great myths of human sexuality. West Sussex, UK: John Wiley \& Sons; 2015.

17. Rao KV, Demaris A. Coital frequency among married and cohabiting couples in the United States. J Biosoc Sci 1995; 27:135-150.

18. Delva W, Meng F, Beauclair R, Deprez N, Temmerman M, Welte A, Hens N. Coital frequency and condom use in monogamous and concurrent sexual relationships in Cape Town, South Africa. J Int AIDS Soc 2013; 16:18034.

19. Younis I, Daifulla AE, Abdel Raouf S. Coital frequency in a sample of Egyptian women. Hum Androl 2017; 7:73-83.

20. Zilbergeld B. The new male sexuality. New York: Bantam Books; 1992.

21. Ablow K. Thanks for taking this poll. Available at: http://drkeith.warnerbros.com/. [Accessed May 30,2020].

22. Corty EW, Guardiani JM. Canadian and American sex therapists' perceptions of normal and abnormal ejaculatory latencies: how long should intercourse last?. J Sex Med 2008; 5:1251-1256.

23. Waldinger MD, Quinn $\mathrm{P}$, Dilleen $\mathrm{M}$, Mundayat R, Boolell M, Schweitzer DH. A multi-national population survey of intravaginal ejaculation latency time. J Sex Med 2005; 2:492-497.

24. Gurvinder K, Alka S, Charles P. Sexuality: desire, activity and intimacy in the elderly. Indian $\mathrm{J}$ Psychiatry 2011; 53:300-306.

25. Gray C. Sexual myths still persist. Can Med Assoc J 1982; 126:981-987.

26. Lindau ST, Schumm LP, Laumann EO, Levinson W, O'Muircheartaigh CA, Waite LJ. A study of sexuality and health among older adults in the United States. N Engl J Med 2007; 357:762-774.

27. Winn R, Newton N. Sexuality in aging: a study of 106 cultures. Arch Sex Behav 1982; 11:283-298.

28. Levine S. Sexuality in mid-life. New York: Plenum Press; 1998. 91

29. Tiggemann M, Hodgson S. The hairlessness norm extended: reasons for and predictors of women's body hair removal at different body sites.
Sex Roles 2008; 59:889-897.

30. Gades NM, Jacobson DJ, McGree ME, Sauver JL, Lieber MM, Nehra A, et al. The associations between serum sex hormones, erectile function, and sex drive. J Sex Med 2008; 5:2209-2220.

31. Collins S. Men's voices and women's choices. Anim Behav 2000; 60:773-780.

32. Knussmann R, Christiansen K, Kannmacher J. Relations between sex hormone level and characters of hair and skin in healthy young men. Am J Phys Anthropol 1992; 88:59-67.

33. Loeb H. HHarnrohrencapacitat und Tripperspritzen, MunchenMedizinische, Wochenschrift (Urethral capacitat and gonorrhea injections, Munchen Medical, Wochenschrift) 1899; 46:1016-1019.

34. Siminoski K, Bain J. The relationships among height, penile length, and shoes size. Ann Sex Res 1993; 6:231-235.

35. Wusu O, Isiugo-Abanihe U. Understanding sexual negotiation between marital partners: a study of Ogu families in Southwestern Nigeria. Etude Popul Afr $2013 ; 23: 2$.

36. Vannier S, O'Sullivan L. Communicating interest in sex: verbal and nonverbal initiation of sexual activity in young adults' romantic dating relationships. Arch Sex Behav 2011; 40:961-969.

37. Dworkin S, O'Sullivan L. Actual versus desired initiation patterns among a sample of college men: tapping disjunctures within traditional male sexual scripts. J Sex Res 2005; 42:150-158.

38. Gaskins AJ, Sundaram R, Louis B, Germaine M, Chavarro JE. Seafood intake, sexual activity, and time to pregnancy. J Clin Endocrinol Metab 2018; 103:2680-2688.

39. Cai T, Gacci M, Mattivi F, Mondaini N, Migno S, Boddi $\mathrm{V}$, et al. Apple consumption is related to better sexual quality of life in young women. Arch Gynecol Obstet 2014; 290:93-98.

40. Salonia A, Fabbri F, Zanni G, Briganti A, Fantini $\mathrm{G}$, Lognhi E, et al. Chocolate and women's sexual health. An intriguing correlation: MP-3-7. J Sex Med 2006; 3:476-482.

41. Mirza RA, Poisson JJ, Fisher GH, D’Aniello, A, Spinelli P, FerrandinoG. Do marine mollusks possess

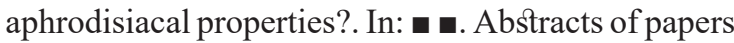
of the American chemical society. Washington, DC, USA: Am Chemical Soc; 2005. 229:U180-U180.

42. FDA. Raw oyster myths. Available at: https://www. fda.gov/food/health-educators/raw-oyster-myths. [Accessed June 2, 2020]. 
43. Rinchaw DC. Understanding masturbation. J Sch Health 1976; 46:98-101.

44. Groenendijk LF. Masturbation and neurasthenia: Freud and Stekel in debate on the harmful effects of autoerotism. J Psychol Hum Sex 1997; 9:71-94.

45. Kinsey AC, Pomeroy WB, Martin CE. Sexual behavior in the human male. Philadelphia: W.B. Saunders; 1948.

46. Kinsey AC, Pomeroy WB, Martin CE, Gebhard PH. Sexual behavior in the human female. Philadelphia: B. Saunders Co.; 1953.

47. Masters WH, Johnson VE. Human sexual response. Boston: Little, Brown and Company; 1966. 